\title{
Comparing the seasonal productivity of cocksfoot and resident pastures on hill country farms using a system model
}

\author{
D. J. BARKER and J. A. BAARS \\ AgResearch Grasslands, Private Bag 11008, Palmerston North \\ 'AgResearch Whatawhata, Private Bag 3089, Hamilton
}

\begin{abstract}
Grasslands Wana cocksfoot (Dactylis glomerata) has potential for use in hill country, especially dry hill country. Although Wana can have slow spring growth it is usually more productive in summer and autumn. Prior to large-scale field evaluation, strategies for incorporating significant areas of new species into farming systems can be evaluated with a farm-system model. The objective of this work was to use the farm-system model, Stockpol, to investigate the influence of $0,33,66$, or $100 \%$ of a farm sown to Wana, on bull beef or breeding ewe enterprise productivity. Three scenarios, in which annual herbage dry matter production from Wana was $-14 \%,+13 \%$, and $+41 \%$ relative to resident pasture controls, were identified from field trials and tested with the model. A strong relationship between annual production and stocking rate was found, with a lesser influence from seasonal distribution of production. 'The system model was a useful tool to compare these pastures, and highlighted deficiencies in our knowledge of cocksfoot.
\end{abstract}

Keywords: Dactylis glomerata, farm system, Grasslands Wana, hill country, model, seasonal pasture production

\section{Introduction}

The role of grass species in pasture improvement has always been of interest to hill country farmers. Given adequate fencing, fertiliser and legumes, the introduction of a new grass species may offer potential for further pasture improvement (Barker et al. 1993b). Webby et al. (1990) found in a grazing trial that introduction of new cultivars increased pasture and animal production, but failure of prairie grass (Bromus willdenowii) and managing lambs and bulls with priority over breeding stock, resulted in no profit after 2 years. Similar studies (Frengley \& Anderson 1989; Parminter 1991) have found pasture renovation can be profitable but that other factors related to management and utilisation can have greater impact on profitability than productivity per se.
Grasslands Wana cocksfoot (Dactylis glomerata) has shown potential for use in New Zealand hill country (Rumbal1 1982). It can be successfully established in drought-prone environments (Milne \& Fraser 1990), is persistent under sheep grazing in hill country (Barker et al. 1985), provides additional feed in summer and autumn (Webby et al. 1990). and has between 040\% greater annual herbage production than resident pastures (Barker et al. 1993b). Wana has a different seasonal production curve than resident browntop (Agrostis capillaris) or ryegrass (Lolium perenne) pastures, being slower in the spring, but more productive in summer and autumn. Establishment of a significant proportion of a farm area with Wana might therefore allow greater grazing pressure to control reproductive growth of resident pastures during spring, and the possibility of improved quality of these pastures during summer.

Before incorporating significant areas of new species into a farm system, the expected effect can be evaluated with a system-model such as Stockpol (Marshall et al. 1991). Hill country farms vary in their animal production systems, and the benefit of an introduced grass species will vary accordingly. Biological and economic response will vary for store lamb and cow-calf systems, and for beef- and lamb-meat systems. Webby et al. (1990) found in a grazing trial with Wana, that ewe performance and lamb growth rates were more sensitive indicators of production than bull or ewe wool weight. In contrast, however, Parminter (1991) found the enterprise was less important than maintaining high per animal performance, in evaluating the economics of pasture improvement.

The objective of this work was to use the farmsystem model, Stockpol, to investigate the influence of varying the proportion of a farm area sown to Wana, on bull beef and breeding ewe enterprise productivity.

\section{Methods}

Pasture production scenarios

Seasonal production curves of Wana-based and resident pastures were obtained from 3 sheep-grazed trials of 56 years' duration in hill country (Figure $1 \mathbf{a}, \mathbf{b}, \mathbf{c}$ ). Pasture production was measured during regrowth periods averaging 56 days, usually with a cut-and-trim technique and exclusion cages. For each regrowth period, 
production was apportioned to respective months, and growth rates averaged for each month for the duration of the trial (Figure la,b,c). For each site, the initial (establishment) year after oversowing Wana was omitted from analysis. The trials represented 3 production patterns:

A) $14 \%$ lower total annual pasture production from Wana than resident pastures, but with similar production in autum (Figure la). This occurred on a north-west-facing, $24^{\circ}$ slope of low natural fertility ( $\mathrm{pH}=5.3$, Olsen $\mathrm{P}=4 \mu \mathrm{g} \mathrm{P} / \mathrm{g}$ soil) at Rawhiti Station in central Wairarapa (annual rainfall 790 mm) (Barker et al. 1993a). On average Wana contributed $66 \%$ and resident ryegrass contributed $77 \%$ of the dry matter of their respective pastures.

B) $13 \%$ greater annual pasture production from Wanabased than resident pastures, but with similar production in spring (Fig. lb). This occurred on a west-facing, $15-25^{\circ}$ slope of moderate fertility $(\mathrm{pH}=$ 5.4, Olsen $\mathrm{P}=13-20 \mu \mathrm{g} \mathrm{P} / \mathrm{g}$ soil) at the Massey University farm, Riverside, in northern Wairarapa (annual rainfall $1200 \mathrm{~mm}$ ) (Mackay et al. unpublished) (Figure $\mathrm{lb}$ ). The resident pasture was dominated by browntop, with lesser amounts of ryegrass and suckling clover (Trifolium dubium). Wana pastures comprised 44\% cocksfoot (Mackay et al. 1990).

C) $41 \%$ greater annual pasture production from Wana than resident pastures (Figure lc). This occurred on a northern face of $28^{\circ}$ slope and low fertility ( $\mathrm{pH}=5.2$, Olsen $\mathrm{P}=6 \mu \mathrm{g} \mathrm{P} / \mathrm{g}$ soil) at the AgResearch hill country research farm, Ballantrae, near the Manawatu Gorge (annual rainfall $1200 \mathrm{~mm}$ ) (Barker \& Dymock 1993) (Figure lc). The resident pasture comprised 25\% chewings fescue (Festuca rubra ssp. commutata), $25 \%$ browntop, $15 \%$ sweet vernal (Anthoxanthum odoratum), $15 \%$ perennial ryegrass, 5\% crested dogstail (Cynosurus cristatus), 8\% white clover (T. repens), and $7 \%$ other species. Wana pastures comprised $67 \%$ cocksfoot.

\section{Stockpol}

The model (Marshall et al. 1991) consisted of feed, animal and economic components. The potential pasture growth rates that had been collected with the "cut-andtrim" technique (Figure la,b,c) were entered from the keyboard, but subsequently were adjusted by Stockpol to values more likely under continuous grazing. Seasonal senescence and decay parameters were used to determine the amount of green (leaf and stem) and dead pasture available. Potential animal intake was determined for
Figure 1 Seasonal pasture growth rates for Wana and resident pastures at (a) Rawhiti, central Wairarapa, (b) Riverside, northern Wairarapa, and (c) Ballantrae, southern Hawkes Bay, determined by the "cut-andtrim" technique with exclosure cages.

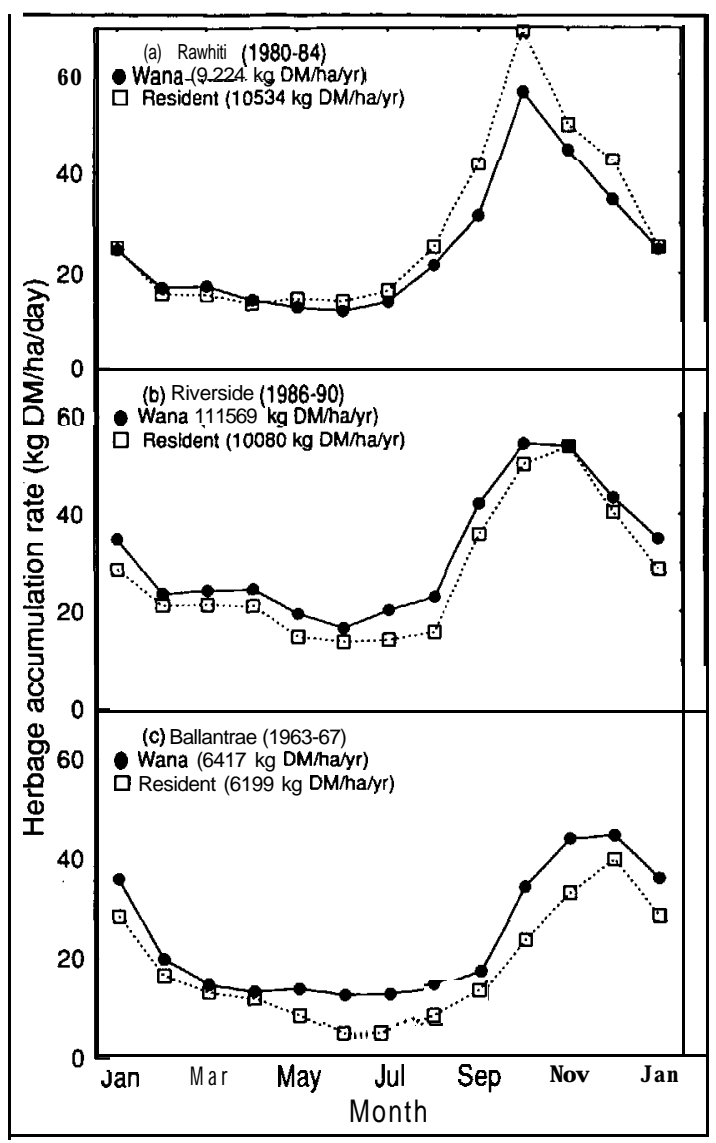

each stock class based on herbage mass on the total farm and proportions of green, leaf and stem of the pasture components. Animal growth was determined using an energy balance approach. Animal production variables such as liveweight gain, weaning weight and wool weight were determined by liveweight and breed. Economic components of the model were included to value animal production (income less shearing and/or animal health) for the various production scenarios. Pasture production was adjusted for the metabolisable energy concentration of the green leaf, stem and dead fractions (Ulyatt et al. 1980; Barker et al. 1993a; T. Fraser pers. comm.). The same tissue-cycling model was used for ryegrass, browntop and cocksfoot swards. In addition to $100 \%$ of the farm area in Wana-based or resident pasture, Stockpol tested various proportions $(33 \%$ and $66 \%$ ) of a 100 ha farm sown in Wana. 
Farm enterprises

Stockpol tested 12 pasture scenarios (3 sites x 4 Wana "proportions") for each of 2 animal enterprises, bull beef and breeding ewes (24 runs in total).

The bull beef assumptions were: Friesian bull calves bought on 15 November at $100 \mathrm{~kg}$ liveweight; drafted from the system $>453 \mathrm{~kg}$ on 15 January, $>450 \mathrm{~kg}$ on 15 February and the remainder on 15 March, at approximately $\$ 2.42 \mathrm{~kg}$ carcass weight; growth targets were set at $0.5,0.7,0.9,1.1,1.3,1.0,0.8,0.3,0.3 \mathrm{~kg}$ / day for the respective months July-March

The breeding ewe assumptions were: Romney breed; start of mating 1 April; $110 \%$ lambing beginning 26 August with a target herbage mass of $1400 \mathrm{~kg}$ DM/ha; weaning 18 November at approximately $21 \mathrm{~kg}$; first drafting of lambs on 15 April above $35 \mathrm{~kg}$ liveweight, and all surplus lambs sold prime on 15 May, at approximately $\$ 2.64 \mathrm{~kg}$ carcass weight; $5.8 \mathrm{~kg}$ wool per sheep-stock-unit @ \$3.80 /kg; 24\% ewe replacement rate and $5 \%$ ewe death rate.

No supplements were "fed" with either enterprise, but hay was sometimes removed from the systems at Rawhiti and Riverside to avoid quality problems from excessive herbage mass.

\section{Results}

In the model, pasture growth was reduced on average by $24.6 \%$ compared with the exclosure cage data measured (Figure I), based on the difference in herbage mass, and hence accumulation rate, between exclosure cages and a continuously grazed pasture (Figure 2). This effect was greater for faster-growing (spring) than slower-growing (winter) pastures. There was a strong relationship between annual pasture production and predicted farm stocking rate (Figure 2) $\left(\mathbf{R}^{2}=\mathbf{9 4 . 5 \%}\right)$, and on average for the three sites a $633 \mathrm{~kg}$ DM/ha increase in production supported one additional ewe equivalent/ ha. Variation from this general relationship occurred within each site on account of the different influence of Wana on the system (Figure 2). In every case, the breeding ewe enterprise could support a higher stocking rate than cattle (based on the model equivalence of 4 ewes $=1$ bull) resulting from the lower herbage mass requirement of sheep.

The effect of increments in cocksfoot proportion of the farm varied between the three sites. With $100 \%$ of farm area in Wana, the $39 \%$ and $17 \%$ greater herbage production at Ballantrae and Riverside, respectively, resulted in $46 \%$ and $19 \%$ higher stocking capacity (Figure 2), and 39\% and 16\% higher net income (Figure 3), compared with resident pasture for the two sites. These responses tended to be slightly greater for bull than breeding ewe systems. For the bull system at Rawhiti,
Figure 2 The relationships between annual pasture production and stocking rate for breeding ewe (open symbols) sad bull (closed symbols) enterprises at three sites (with varying productivity of resident pasture) sad for varying proportions of the farm sown to Grasslands Wana cocksfoot $(0,33,66$, and $100 \%)$, as predicted by Stockpol.

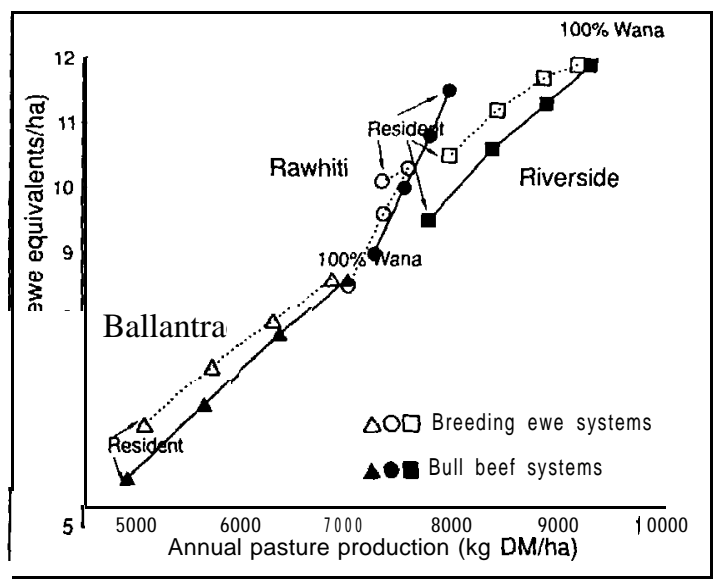

Figure 3 The effect on projected animal net income (\$ha) from establishing a proportion of a farm area with Grasslands Wana cocksfoot for breeding ewe (open symbols) and bull (closed symbols) enterprises at three sites (with varying productivity of resident pasture).

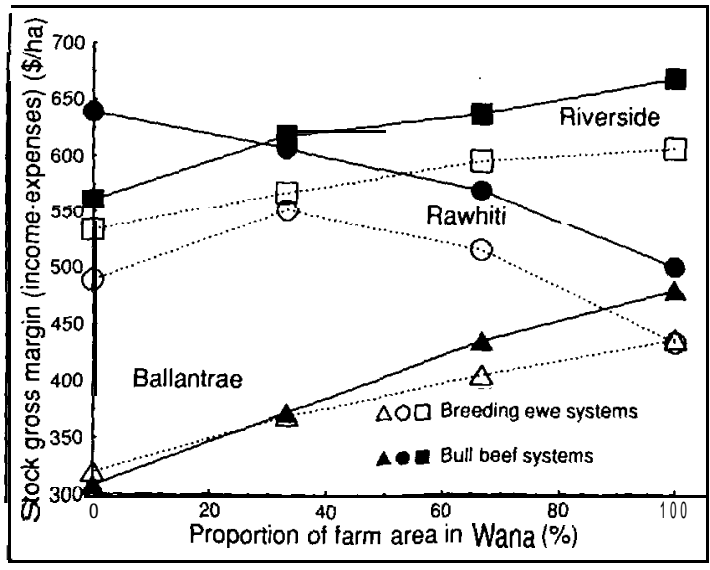

adding Wana pastures to a farm system decreased pasture productivity slightly, and decreased stocking rate and animal income by a proportionately larger amount regardless of Wana proportion. For the breeding ewe system at Rawhiti, adding Wana pastures to $33 \%$ of a system increased pasture production, stocking capacity, and animal income, but further increments in proportion decreased stocking capacity and income (Figure 3). 
Maximum farm cover occurred in summer (December-February) for all systems. Including Wana as some proportion of the farm reduced the maximum farm cover for all production scenarios (Table 1). Removal of hay from the resident pastures systems at Riverside and Rawhiti was necessary to prevent quality problems resulting from excessive farm covers.

Table 1 Maximum farm cover ( $\mathrm{kg} \mathrm{DM} / \mathrm{ha}$ ) for bull beef and breeding ewe enterprises at three sites and for varying proportion of a farm sown to Grasslands Wana cocksfoot.

\begin{tabular}{lcccc}
\hline \multicolumn{5}{c}{ Proportion of farm area } \\
Wana & $100 \%$ & $67 \%$ & $33 \%$ & $0 \%$ \\
Resident & $0 \%$ & $33 \%$ & $67 \%$ & $100 \%$ \\
\hline \multicolumn{5}{c}{ kg } \\
Maximum farm cover $=$ Bull beef \\
Rawhiti & 2354 & 2325 & 2424 & 2531 \\
Riverside & 2191 & 2185 & 2210 & 2357 \\
Ballantrae & 2171 & 2198 & 2279 & 2391 \\
Maximum farm cover-Breeding & ewe & & \\
Rawhiti & 2491 & 2282 & 2357 & 2423 \\
Riverside & 2281 & 2196 & 2185 & 2209 \\
Ballantrae & 2423 & 2352 & 2250 & 2296 \\
\hline
\end{tabular}

\section{Discussion}

Stockpol was useful in predicting the response from inclusion of a different pasture species on a proportion of farm area. By comparing various production scenarios, it was predicted that the benefits of a new species were greater from improved annual pasture production than a change in seasonality of production. This effect was more likely for poorer pastures. The reduced spring growth and increased summer growth of Wana had relatively minor benefits on animal production and income, but had qualitative benefits in reducing farm herbage mass, which avoided the need for removing surpluses as hay to maintain forage quality. Of particular interest was the result for breeding ewes at Rawhiti, where the mix of pasture types within a farm was potentially more productive and profitable than if sown entirely to a single pasture type,

The maximum farm herbage mass varied among systems, and was always lower for systems including Wana-based pastures. The model may not have fully accounted for the less tangible costs, such as reduced pasture quality resulting from these greater surpluses.

At two sites the breeding ewe and bull enterprise stocking rate and net income behaved similarly in relation to increasing the proportion of Wana. At Rawhiti, however, the bull enterprise showed reduced stocking rate and net income from introduced Wana.
Bulls may have better utilised the relatively high herbage growth rates that occurred in the resident pastures compared with breeding ewes.

Limitations with the model did occur, arising both from the assumptions of the model, and limitations to our knowledge of pasture performance, particularly of cocksfoot. The extent and impact of flowering on cocksfoot quality compared with ryegrass is not known, and was assumed to be the same as that on ryegrass. In addition, if Wana was sown as a significant proportion of a farm area, there could be opportunity for greater control of resident pastures in spring, with consequent benefits to the quality of these pastures during summer. This could not be tested by Stockpol.

\section{ACKNOWLEDGEMENTS}

The authors thank P.R. Marshall and K. Johns for assistance with running Stockpol; A.D. Mackay, and R.W. Tillman for making unpublished data available; Mrs Jean Laing, Rawhiti Station, for provision of land and stock; N. Dymock, C.B. Anderson, D. Johnston, V. Pokaia for technical assistance, and D.G. McCall and B. Butler for valuable discussion.

\section{REFERENCES}

Barker, D.J.; Dymock, N. 1993: Introduction, production and persistence of five grass species in dry hill country 6. Ballantrae. New Zealand journal of agricultural research 36: 41-47.

Barker, D.J.; Lambert, M.G.; Dymock, N.; Gray, Y.S. 1993a. Introduction, production and persistence of five grass species in dry hill country 5 . Central Wairarapa. New Zealand journal of agricultural research 36: 29-39.

Barker, D.J.; Lancashire, J.A.; Meurk, C. 1985. 'Grasslands Wana' cocksfoot - An improved grass suitable for hill country. Proceedings of the New Zealand Grassland Association 46: 167- 172.

Barker, D.J.; Stevens, D.R.; Lancashire, J.A.; Scott, D.; Moloney, SC.; Turner, J.D.; Dymock, N.; Archie, W.J. 1993b. Introduction, production and persistence of five grass species in dry hill country 8 . Summary and Conclusions. New Zealand journal of agricultural research 36: 61-66.

Frengley, G.A.G.; Anderson, C.J. 1989. Pragmatism in hill pasture renovation. Proceedings of the New Zealand Grassland Association 50: 15 1- 156.

Mackay, A.D.; Tillman, R.W.; Parker, W.J.; Barker, D.J. 1990. Effect of superphosphate, lime, and cocksfoot on summer dry hill country pasture production. Proceedings of the New Zealand Grassland Association 51: 131-134. 
Marshall, P.R. 1991. Stockpol: A decision support model for livestock farms. Proceedings of the New Zealand Grassland Association 53: 137- 140.

Milne, G.; Fraser, T. 1990. Establishment of 1600 hectares in dryland species around Oamaru/Timaru. Proceedings of the New Zealand Grassland Association 52: 133-137.

Parminter, T.G. 1991: Financial evaluation of hill country pasture improvement. Proceedings of the New Zealand Grassland Association 53: 117-12 1.

Rumball, W. 1982: 'Grasslands Wana' cocksfoot (Dactylis glomerata). New Zealand journal of experimental agriculture 10: 5 t-52.

Ulyatt, M.J.; Fennessy, P.F.; Rattray, P.V.; Jagusch, K.T. 1980. The nutritive value of supplements. In Supplementary feeding $\boldsymbol{-}$ a guide to the production and feeding of supplements for sheep and cattle in New Zealand. New Zealand Society of Animal Production Occasional Publication No. 7. Drew, K.R.; Fennessy, P.F. eds

Webby, R.W.; Sheath, G.W.; Boom, C.J. 1990. Performance of new pasture cultivars in a hill country finishing system. Proceedings of the New Zealand Grassland Association 51: 15 1 156. 